\title{
Az állománystruktúra és a levélfelület index térbeli mintázatának vizsgálata a síkfökúti cseres-tölgyes mintaterületen
}

\author{
Adorján Balázs, Oláh Viktor, Kanalas Péter, Nyitrai Balázs \\ és Mészáros Ilona* \\ Debreceni Egyetem Természettudományi és Technológiai Kar Növénytani Tanszék \\ 4032 Debrecen, Egyetem tér 1. \\ e-mail*:immeszaros@unideb.hu
}

\begin{abstract}
Összefoglaló: Jelen munkában a Síkfőkút LTER kutatási terület korábban fapusztulással erősen érintett cseres-kocsánytalan tölgyes faállományában bekövetkezett változásokat vizsgáltuk a törzsdenzitás, a körlapösszeg, mint fő struktúra-jellemzők és a müködés szempontjából meghatározó levélfelület index (LAI) térbeli mintázatának elemzésével. Az erdőállományban az 1970-es évek végétől kezdődően föként a kocsánytalan tölgy (Quercus petraea) egyedszáma csökkent, ami azonban teret nyitott a cserjeszintben előforduló fajok lékekbe való felnövésének. A megjelenő második lombkoronaszintben elsősorban a mezei juhar (Acer campestre) található meg jelentős számban, ezért a munkánk során a tölgyek mellett e fajnak a lombkoronaszintben betöltött szerepét is vizsgáltuk. Az elemzésekhez térinformatikai módszerekkel generált térképeket használtunk fel. A LAI térbeli mintázatát összevetve a különböző fajok egyedeinek lokális törzsdenzitásával megállapítottuk, hogy a mezei juhar az átlagosnál magasabb, a kocsánytalan tölgy leromlott állapotú illetve elpusztult fái pedig alacsonyabb levélfelület indexet eredményeznek, ami megjelenik a LAI térbeli mintázatában is. Az eredményeink arra is rámutattak, hogy a pusztuláson átesett erdőben a jelenlegi faállomány és az egyes fafajok törzsdenzitásának és körlapösszegének térbeli mintázata nagy heterogenitást mutat, ugyanakkor a LAI-ra kisebb térbeli különbségek jellemzőek.
\end{abstract}

Kulcsszavak: LAI, klímaváltozás, erdőátalakulás, mezei juhar, kocsánytalan tölgy, csertölgy

\section{Bevezetés}

Az erdő faállományának jellemzői és egészségállapota döntően meghatározza az erdők klímamódosító, szénmegkötő és raktározó képességét. Az utóbbi évtizedekben végzett kutatások az európai erdőkben a mortalitás felerősödésére és egyes fajok visszaszorulására mutattak rá (Führer 1998). A folyamat megértése, az okok és a következmények feltárása az erdőökológia számára komoly kihívásokat jelent. Az erdő faállományában bekövetkező változásoknak természetvédelmi biológiai 
szempontból is kiemelkedő jelentősége van, hiszen közvetlenül vagy közvetve befolyásolják az erdei biodiverzitást. A faállomány állományon belüli fényklímát, mikroklimatikus és edafikus feltételeket befolyásoló hatásai kisebb vagy nagyobb mértékben minden élőlénycsoportot érintenek (Király \& Ódor 2010).

Az erdők egészségállapotában bekövetkező leromlás pontos okait nem egyszerü meghatározni, rendszerint több abiotikus és biotikus stressz tényező komplex hatására vezethető vissza. Az európai erdőségekben fellépő fapusztulásokat a klímaváltozással egyre gyakrabban megjelenő extrém időjárási eseményekkel, aszállyal és/vagy hőhullámokkal, mint elsődleges kiváltó tényezőkkel hozzák összefüggésbe (Mátyás \& Czimber 2004). A hazai vizsgálatok alapján a zonális fafajaink egészségállapotának leromlása és a termőhelyeik nyári félévi vízhiánya között szoros összefüggés mutatható ki, ami szintén az aszály fontos szerepére utal (Berki \& Rasztovits 2004). A jövőben várható klímaváltozási trendek miatt különösen az ún. peremhelyzetű erdőállományok állapota súlyosbodhat (Móricz et al. 2013), mint a jelen munkában vizsgált állományé is, ahol már eddig is jelentős vitalitásgyengülést (Jakucs et al. 1986) és mortalitást figyeltek meg (Tóth 2013).

Az erdődinamikai folyamatok vizsgálatában fontos szerepet kapnak a hosszú távú kutatások, amelyeket nemzetközi LTER kutatási hálózatok keretében összehangoltan végeznek és a sokszor több évtizedes adatbázisaik is hozzáférhetőek. Az erdőket tekintve hazánkban a legtöbb eredmény a Bükk hegységben található Síkfőkút Project LTER (LTER_EU_HU_004) kutatóbázison született, amelyet a hazai legfontosabb erdőtársulás, a cseres-tölgyes (Quercetum petreae-cerris) egyik állományában alapítottak 1972-ben (Jakucs 1985). A Síkfökút Project erdőállományát a hazánkban az 1980-as években tetőző tölgypusztulás az országos átlaghoz képest jóval súlyosabban érintette. A pusztulási folyamatról és az azt követően lejátszódó állományszerkezeti változásokról több kutatócsoport részéről állnak rendelkezésre publikált és/vagy archivált eredmények, amelyek közül a jelen munkához kapcsolódóan a következőket emeljük ki. Az állományban az 1973-ban végzett, első struktúra felvételezés adatokhoz képest (Jakucs 1985) napjainkig a tölgyfák 64\%-a pusztult el. A fapusztulás nagy része az 1970-es évek vége és az 1990-es évek közepe közötti időszakban ment végbe és elsősorban a kocsánytalan tölgy állományát érintette (Jakucs et al. 1986), napjainkra ennél a fajnál a mortalitás meghaladja a 70\%-ot. Jóval kisebb mértékü (19\%) volt a fapusztulás a csertölgy esetében (Kotroczó et al. 2007, Mészáros et al. 2007, Tóth 2013).

Az erdőállományban a tölgypusztulás fő időszakát követően megkezdődött a lombkorona nyiladékok, lékek „,begyógyulása”. Ebben a megmaradó tölgyfák lombkoronájának a terebélyesedése mellett (Mészáros et al. 2007) a magas cser- 
jeszint fajai, közülük is elsősorban az Acer campestre lombkoronaszintbe történő felnövése játszott szerepet, melynek következtében kialakult egy második lombkoronaszint (Kotroczó et al. 2007). E folyamatok eredményeként egyik tölgyfaj sem újult fel, az alacsony cserjeszint visszaszorult, a magas cserjeszint pedig megerősödött (Misik et al. 2014).

Az erdők müködési jellemzői közül a leggyakrabban az egységnyi talajfelszínre vonatkoztatott összes levélfelület nagyságát, a levélfelület indexet (Leaf Area Index, LAI $\mathrm{m}^{2} \mathrm{~m}^{-2}$ ) mérik, direkt vagy indirekt módszerek alkalmazásával (Bréda 2003). Az előbbi, egyedi levelek területmérésén (pl. gyüjtött avarból) alapuló eljárások pontosabb eredményt adnak, de nagyobb mérési területek esetében jobban alkalmazhatóak az utóbbiak, a lombkorona fényáteresztő képességét mérő műszeres módszerek (Bréda 2003, Cutini et al. 1998). Az asszimilációs felület súlyos csökkenésével járó erdőkárok és zavarások után az állományszintű szénés vízmérleg, a fotoszintézis és transzspirációs ráta helyreállásában a LAI-nak meghatározó szerepe van. Feltételezhető, hogy akár a folyó növedék rovására, de a LAI regenerálódása a zavarást megelöző szintre viszonylag rövid időn belül megtörténik, összevetve pl. a faállomány biomasszájának a lassú, akár több évtizedet felölelö helyreállásával (Trumbore et al. 2015).

A jelen munka célkitüzése kettős volt. Egyrészt, hogy a síkfőkúti cseres-tölgyes erdőben a faállomány struktúrájára vonatkozó archivált és saját kutatási eredmények alapján megvizsgáljuk egyes térinformatikai módszerek alkalmazhatóságát a strukturális jellemzők finom térbeli mintázatának a feltárásában. Másrészt célunk volt annak a vizsgálata, hogy a korábban tölgypusztulást elszenvedő állományban jelenleg milyen a levélfelület index térbeli variabilitása és az hogyan függ össze i) a korábbi fapusztulások térbeli mintázatával, ii) a főbb fafajok jelenlegi térbeli elhelyezkedésével, iii) a beteg és holt fák előfordulási mintázatával.

\section{Anyagok és módszerek}

A vizsgálatokat a Bükk és a Bükkalja határán fekvő Síkfökút LTER kutatóterületen végeztük $\left(47^{\circ} 90^{\prime} \mathrm{N}, 20^{\circ} 46^{\prime} \mathrm{E}\right)$. A 320-340 m tengerszint feletti magasságban elhelyezkedő, 105-110 éves, sarjeredetủ erdőállomány felső lombkoronaszintjében domináns a csertölgy (Quercus cerris L.) és a kocsánytalan tölgy (Quercus petraea (Matt.) Liebl.), illetve alacsony összesített egyedszámmal $\left(<30\right.$ ind. ha $\left.{ }^{-1}\right)$ a madárcseresznye (Cerasus avium (L.) Moench) és a gyertyán (Carpinus betulus L.) is megtalálható. Az erdóállomány alsó lombkoronaszintjében domináns a mezei juhar (Acer campestre L.), illetve szórványosan megtalálható még a tatárjuhar (Acer tataricum L.) és a húsos som (Cornus mas L.) (Kotroczó et al. 
2007). A cserjeszint fajai a veresgyürủ som (Cornus sanguinea L.), a galagonyafajok (Crataegus spp.), a fagyal (Ligustrum vulgare L.), a bibircses kecskerágó (Euonymus verrucosus Scop.) és az alsó lombkoronaszintben is jelenlévő fajok (Misik et al. 2013).

A területen 30 év átlagában (1982-2011) az évi csapadékösszeg 552 156

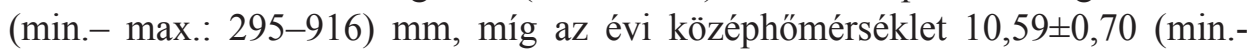
max.: 9,26-12,16) ${ }^{\circ} \mathrm{C}$. Az erdőállomány a klimatikus viszonyok alapján az erdő és erdős-sztyepp zónák határán helyezkedik el.

A vizsgálataink során a faállomány strukturális jellemzőinek a felmérését 2012 nyarán végeztük. Az erdő állandó monitorozásra kijelölt 100×100 m-es területén, $4 \mathrm{db} 50 \times 50$ m-es parcellában $(\mathrm{A}, \mathrm{B}, \mathrm{C}, \mathrm{D})$ megmértük a faállomány három legnagyobb egyedszámmal jelenlévő fajánál ( $Q$. cerris, $Q$. petraea, A. campestre) a mellmagasságban $(1,3 \mathrm{~m}) 10 \mathrm{~cm}$-nél vastagabb fák törzsének az átmérőjét (DBH, $\mathrm{cm})$ és térképen rögzítettük a fák helyét. A kis törzsszámmal előforduló madárcseresznye és gyertyán egyedeit a felmérés során nem vettük figyelembe.

A DBH adatok alapján számoltuk az egyes törzsek körlap méretét $\left(\mathrm{BA}, \mathrm{m}^{2}\right)$. Minden fa esetében felmértük a fák egészségi állapotát a lombkorona jellemzők figyelembevételével az „ICP Forests” erdőmonitoring protokollok ajánlásai alapján (http://www.icp-forests.org/Manual.htm). A legyengült vitalitású fákra jellemző, hogy a lombkoronájuk egy részének az elszáradása ellenére még sokáig életben maradnak, és hozzájárulnak az állományszintủ működési folyamatokhoz. Az ilyen állományrészeken ezeknek a fáknak a pusztulási folyamatától függően a lokális LAI-ban időben módosulások várhatóak. A faállomány három domináns faja közül a kocsánytalan tölgy fáinak az egészségi állapotában jelentős eltérések vannak, ezért a lombkorona állapota alapján a fák három csoportját különítettük el: egészséges fák, csúcsszáraz lombkoronájú (a lombkorona legalább 20\%-át elvesztett) fák és holt, de még lábon álló fák csoportjai.

Térképet készítettünk az állandó monitorozásra kijelölt 100×100 m-es területen a tölgypusztulás következtében elpusztult (kidőlt) fákról, két adatforrás alapján. Ehhez a munkához a kutatási terület adatbázisából felhasználtuk a tölgypusztulást megelőző és a fô pusztulási időszakban készült térképeket, illetve a későbbi saját terepi felméréseink alapján 2012-ig készült térképeket. Mivel a projekt kezdete óta a fák egyedi számjelzésekkel vannak ellátva, az állapotukban bekövetkező változások könnyen nyomon követhetőek.

Az erdőállomány levélfelület indexét a 2012 és 2017 közötti évek vegetációs időszakának a második felében mértük, indirekt módszerrel. A méréseket az állományszerkezet vizsgálatára használt egyhektáros területen egy $10 \times 10$ méteres hálózat rácspontjai mentén végeztük, összesen 81 ponton. A LAI méréséhez LAI2000 mérőmüszert (Li-Cor Biosciences, USA) használtunk, melynek az optikai 
szenzora a zenittől mérve $74^{\circ}$-ig, öt szögtartományban mért fényintenzitás-adatok alapján becsli a lombozat fényelnyelő képességét, ez alapján pedig a vegetáció levélfelület indexét. A mérést minden ponton $0,5 \mathrm{~m}$-es magasságban végeztük. A LAI értékének a megállapításához a lombkorona alatti mérések mellett szükség van tiszta ég alatti ún. referencia-mérésekre is, amiket a kutatóterület meteorológiai tornyának tetején, a lombkoronaszint felett végeztünk el, a lombkorona alatti méréseket közvetlenül megelözően. A LAI térbeli mintázatának a vizsgálatához a mérési pontokon a hat vizsgálati évben mért értékek átlagait használtuk fel.

A mért, pontszerü adatokat a térinformatikai feldolgozás során felületekké alakítottuk, így a vizsgálati területen a LAI területi inhomogenitása vizuálisan öszszevethetővé vált az állományalkotó fák térbeli eloszlásával. A feldolgozáshoz az alábbi interpolációs módszereket használtuk (ArcMap 10.4.1. szoftver, http://pro. arcgis.com):

i) a 10×10 m-es hálózat rácspontjaira a 2012-2017 közti időszakra számolt átlagos LAI értékeket ún. krigeléssel (Li \& Heap 2014), Gauss variogram segítségével interpoláltuk. A legszélső LAI mérések az alaphektár szélétől befelé 10 méteres távolságban történtek. A szegélyhatás kiküszöbölésére a pontállományt önmaga körüli tükrözéssel megtöbbszöröztük, majd a felületet ebből a kiterjesztett állományból készítettük el.

ii) Az élő és holt faegyedek térbeli eloszlását Kernel sűrüség módszerrel dolgoztuk fel, melynek során az algoritmus minden pontra egy adott sugárral lehatárolt, kifelé ereszkedő görbült felületet illeszt, és az egymással átfedő felületeknél az értékek összeadódnak (Alessa et al. 2008). Az eljárásnál a keresési tartomány sugarának megválasztása alapvető fontosságú: túl nagy sugárnál az összesimuló felületek elmossák a területi különbségeket, túl kicsi sugárnál pedig az egyes pontok körül számolt felületek is pontszerüek maradnak (Yang et al. 2006). A vizsgálatainkban a 20 m-es keresési sugár bizonyult megfelelőnek. A számítások elött ezen a pontállományon is elvégeztük a LAI-nál ismertetett tükrözést a szegélyhatás kiküszöbölésére.

A feldolgozás eredményeként a felület egyes pontjaira számolt értékek a lokális törzsszámot $\left(\mathrm{N}_{1}=\right.$ ind. ha $\left.{ }^{-1}\right)$, az egyes fák körlap méretével súlyozva számolt értékek pedig a lokális körlapösszeget $\left(\mathrm{G}_{1}=\mathrm{m}^{2}\right.$ ha $\left.\mathrm{a}^{-1}\right)$ adják meg. Az eljárás során elemeztük a vizsgálati területen élő összes faegyed, az egyes fajokhoz tartozó egyedek, illetve a különböző egészségi állapotú egyedek térbeli eloszlását. Utóbbi esetben a csúcsszáraz és a lábon álló holt - a 2012-es felmérést megelőző években elpusztult - egyedeket összevonva kezeltük, mivel a csúcsszáraz csoportból a LAI mérési években több fa elpusztult. 


\section{Eredmények}

A síkfőkúti erdőállomány 1 ha-os mintaterületén 2012-ben a lábon álló fák (DBH $>10 \mathrm{~cm}$ ) összes törzsszáma $490 \mathrm{db}$, körlapösszege pedig $28,52 \mathrm{~m}^{2}$ volt (1. táblázat). Az összes élő fa száma (N) 2012-ben 464 egyed ha ${ }^{-1}$, körlapösszege pedig

1. táblázat. A különböző egészségi állapotú fák törzsszáma $\left(\mathrm{N}, \mathrm{db}^{\mathrm{h}} \mathrm{a}^{-1}\right)$ és körlapösszege $\left(\mathrm{G}, \mathrm{m}^{2} \mathrm{ha}^{-1}\right)$ a síkfőkúti erdőállomány monitorozásra kijelölt 1 ha-os területén 2012-ben

\begin{tabular}{lcc}
\hline & Törzsszám $(\mathrm{N}) \mathrm{db} \mathrm{ha}^{-1}$ & Körlapösszeg $(\mathrm{G}) \mathrm{m}^{2} \mathrm{ha}^{-1}$ \\
\hline Egészséges fák & 425 & 24,98 \\
Csúcsszáraz fák & 39 & 2,40 \\
Álló holt fák & 26 & 1,14 \\
\hline
\end{tabular}

$27,38 \mathrm{~m}^{2} \mathrm{ha}^{-1}$ volt. Az élő fák 42\%-a (195 egyed ha-1) Q. petraea, 22\%-a (102 egyed ha $\left.{ }^{-1}\right)$ Q. cerris, 36\%-a (167 egyed ha $\left.{ }^{-1}\right)$ pedig A. campestre volt. Az éló fák törzsszámához képest a körlapösszegben $\left(\mathrm{G}=27,38 \mathrm{~m}^{2} \mathrm{ha}^{-1}\right)$ ugyanakkor nagyobb a $Q$. cerris $(53 \%)$, és a $Q$. petraea (38\%), míg jóval alacsonyabb az A. campestre részaránya $(9 \%)$. Az élő fák $9 \%$-a mutatta a csúcsszárazság jeleit (>20\% lombkorona-veszteség), ezek kizárólag kocsánytalan tölgyek voltak. A legalacsonyabb az álló holt fák aránya volt, mindössze $5 \%$.

Az abiotikus és biotikus tényezők eltérései miatt az egyes vizsgálati évek között a LAI erős ingadozást mutatott (1. ábra), ezért a LAI térbeli mintázatát a 2012-2017 közötti időszakban az egyes mérési pontokra számolt hatéves átlagér-

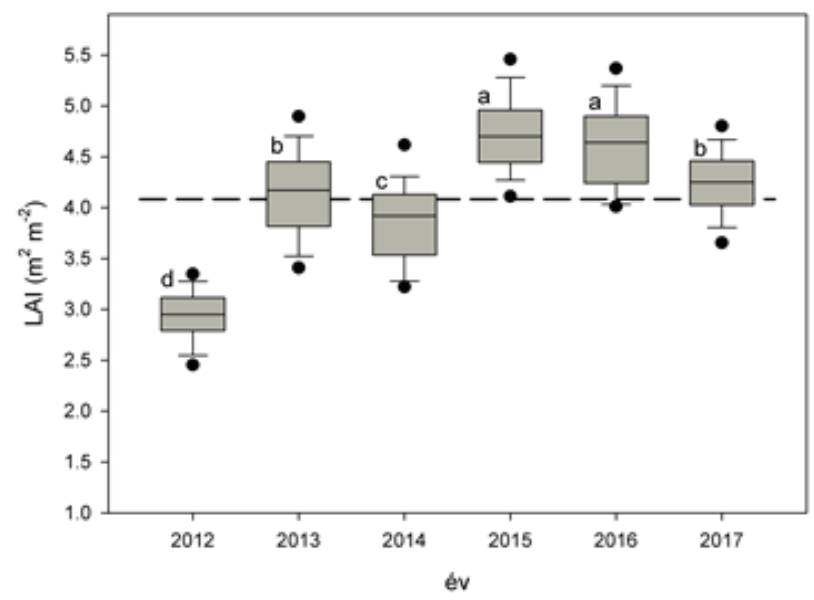

1. ábra: A levélfelület index (LAI m² m²) változása 2012 és 2017 között (szürke színnel, $n=81$ ) és a hat év LAI méréseinek átlaga (szaggatott vonal) a síkfőkúti erdőállományban. A különböző kisbetűk a mediánok szignifikáns ( $\mathrm{p}<0.05)$ különbségét jelzik, Kruskal-Wallis teszt, illetve post-hoc,

Bonferroni-korrigált Mann-Whitney próba alapján (Past 3.15 statisztikai szoftver). 
tékek alapján vizsgáltuk. A variabilitásra példa a 2012-es, kiugróan alacsony érték $\left(2.93 \pm 0.26 \mathrm{~m}^{2} \mathrm{~m}^{-2}\right)$, amely az egymást követő két évben fellépő nyári aszállyal és a vegetációs időszak első felében jelentkező hernyó-gradációval magyarázható. Megfigyeléseink szerint 2012-ben az utóbbi zavarás főleg a hamarabb fakadó mezei juhart és a kocsánytalan tölgyet érintette. Ilyen okok miatt egy-egy vegetációs periódusban végzett mérések helyett egy hosszabb időszak méréseinek az átlagai biztosabban használhatók fel a LAI térbeli mintázatának a vizsgálatában, és az időben stabilabb állománystruktúra jellemzőkkel való összevetésekben. A LAI hatéves középértéke a teljes hektárra 4,08 $\pm 0,23 \mathrm{~m}^{2} \mathrm{~m}^{-2}$ volt (1. ábra). A mintaterületen az egyes években a LAI minimum és maximum értékei mindig ugyanazokon a területrészeken jelentkeztek.

A fák vizsgált jellemzőinek térinformatikai módszerrel történt feldolgozásával készült pontsürüségi térképek jól mutatják, hogy a faállomány struktúrájának a térbeli mintázata jelentős variabilitást mutat. Az élő fák területi eloszlása az A-parcellában, illetve a C-parcella északi sarkában és a D-parcella B-parcellához közeli részén mutatott magas $\mathrm{N}_{1}-\mathrm{t}$, míg a legalacsonyabb értékeket a $\mathrm{C}$-parcella belső részein tapasztaltuk (2. a. ábra). $\mathrm{A} \mathrm{G}_{1}$ homogénebb eloszlást mutatott; a
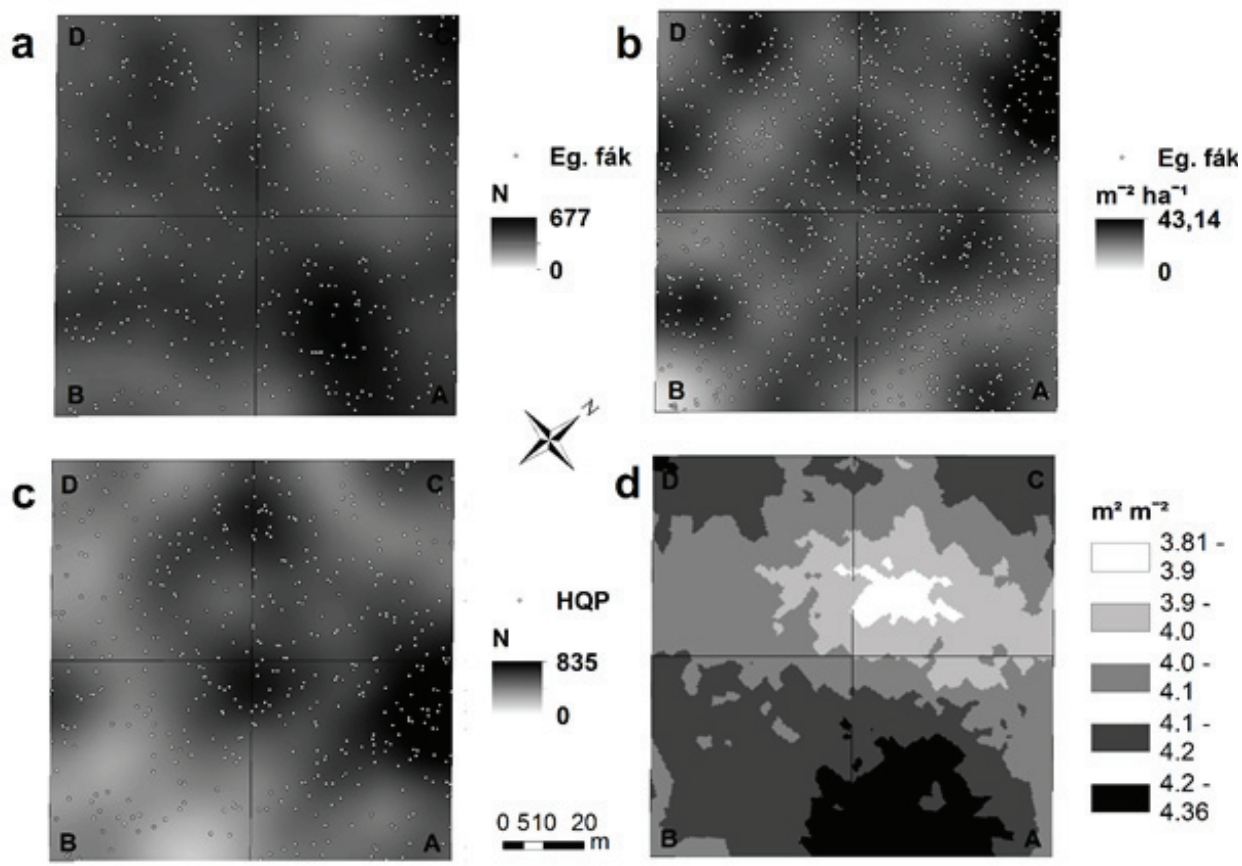

2. ábra: A teljes, élő faállományra vonatkoztatott lokális sürüség $\left(\mathrm{N}_{1} \mathrm{db} \mathrm{ha}^{-1}\right)$ (a) és lokális körlapösszeg $\left(\mathrm{G}_{1}=\mathrm{m}^{2}\right.$ ha $\left.\mathrm{a}^{-1}\right)$ (b) 2012-ben, az 1973-2012 között elpusztult és kidölt $Q$. petraea fák $\mathrm{N}_{1}$ térbeli mintázata (c), a levélfelület index (LAI) 81 ponton mért értékei alapján interpolált felület (a sötétedő színek növekvő értékeket jelentenek) (d) 
legmagasabb értékek a C-parcella északi sarkánál és a B-parcella DNy-i szélénél voltak megfigyelhetök (2. b. ábra).

Az 1973 óta elpusztult és kidőlt fáknak a Kernel sủrüség módszerrel készült pontsürüségi térképén jól kirajzolódik, hogy a faelhalás foltokban következett be és a térbeli mintázatára nagy heterogenitás volt jellemző. A pusztulás a legnagyobb $\mathrm{N}_{1}$ értékekkel $\left(\mathrm{N}_{1}>500 \mathrm{db} \mathrm{ha}^{-1}\right)$ és kiterjedéssel a vizsgálati terület közepén, illetve az A parcella $\mathrm{C}$ parcellához közeli részén és a $\mathrm{C}$ és $\mathrm{D}$ parcellák határán zajlott (2. c. ábra).

A hatéves adatsor alapján interpolált LAI felületen jól kivehető területi különbségek figyelhetők meg (2. d. ábra). A legmagasabb lokális LAI-értékek az A-parcellának a B-parcellához közeli részén jelentek meg, míg a legalacsonyabbak a C-parcella belső részén.

A két struktúrajellemző ( $\mathrm{N}$ illetve $\mathrm{G}$ ) alapján készült térképek az egyes fajok szintjén nagyon hasonló térbeli mintázatot mutattak, ezért a jelen munkában csak a törzsdenzitások elemzése során kapott eredményeket mutatjuk be (3. ábra). A mintaterületen a három fafaj lokális törzsdenzitásának a térbeli mintázata nagymértékben eltér. A csertölgy fáinak a térbeli eloszlása a vizsgálati hektárban nem

a

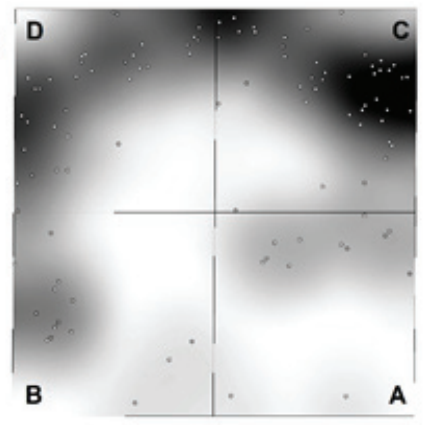

c

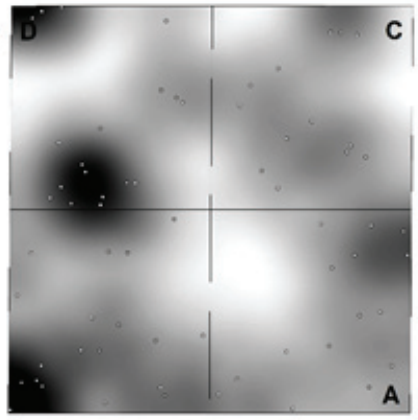

b
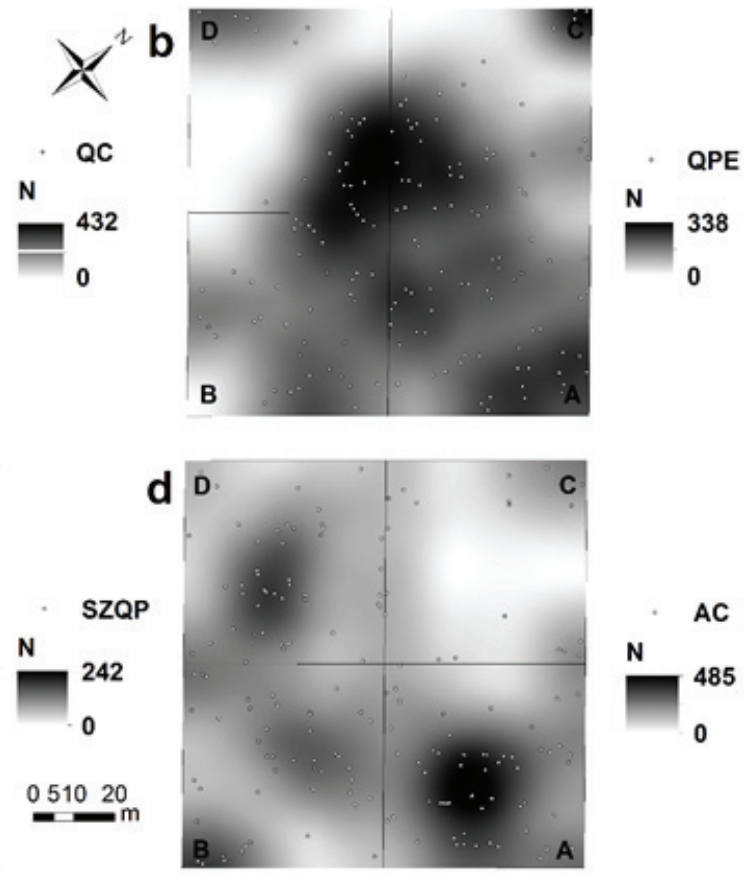

3. ábra: A fafajok lokális törzssürüségének $\left(\mathrm{N}_{1} \mathrm{db} \mathrm{a}^{-1}\right)$ térbeli mintázata a vizsgálati területen: Quercus cerris egészséges fák (a), Quercus petraea egészséges fák (b), Quercus petraea csúcsszáraz és lábon álló holt fák (c) és Acer campestre fák (d) 
egyenletes, magas $\mathrm{N}_{1}$ értékek föként a $\mathrm{C}$ és $\mathrm{D}$ parcellák külső oldalai mentén figyelhetők meg egy félköríves, közel összefüggő foltban (3. a. ábra). A mintaterület többi részén a csertölgy csak elszórtan van jelen és az előző állományrészekhez képest jóval kisebb $\mathrm{N}_{1}$ értékekkel. Ugyanakkor a faállomány csertölgy uralta területein a kocsánytalan tölgy egészséges fái (3. b. ábra) csak szórványosan vannak jelen, ezek a helyek a pontsürüségi térképen alacsony $\mathrm{N}_{1}$ értékkel világos foltok formájában egyértelmủen elkülöníthetők a fajnak a hektár többi részére jellemző magasabb denzitású foltjaitól. A kocsánytalan tölgy egészséges fái a hektár többi részén viszonylag egyenletes elterjedést mutatnak, legnagyobb $\mathrm{N}_{1}$ értékkel a hektár középső részén vannak jelen (3. b. ábra).

A csúcsszáraz és a lábon álló holt fák a legmagasabb $\mathrm{N}_{1}$ értékekkel a $\mathrm{B}$ és $\mathrm{D}$ parcella határától a D-be benyúló nagyobb foltban vannak jelen (3. c. ábra). Ennek a csoportnak a lokális törzsdenzitása viszonylag magas egy az A parcellából a C parcellába átnyúló nagyobb foltban, és egy a $\mathrm{B}$ parcellában megjelenő kisebb sávban is. A csúcsszáraz és holt fák hiányoznak vagy csak nagyon alacsony $\mathrm{N}_{1}$ értékkel vannak jelen a hektárnak a központi részén, az onnan az A parcellára kiterjedő nagyobb foltban és a faállománynak a csertölgy által dominált területein $(\mathrm{C}$ és $\mathrm{D}$ parcellában) (3. c. ábra). Az A. campestre esetében (3. d. ábra) a legmagasabb $\mathrm{N}_{1}$ értékek az A parcellában lévő viszonylag nagy foltban figyelhetők meg. Az $A$. campestre további magas lokális törzsdenzitású foltjai a $\mathrm{B}$ parcellából induló és a $\mathrm{D}$ parcellába áthúzódó sávban találhatóak. A mintaterületnek a két tölgyfaj által dominált részein az $A$. campestre a lombkoronaszintből hiányzik, amit a pontsürüségi térképen a $C$ parcellában egy nagy kiterjedésü fehér folt jelez.

Az interpolációs és pontsürüségi térképek vizuális összehasonlítása alkalmasnak bizonyult arra, hogy faállomány és az egyes fajok struktúrajellemzőinek a térbeli mintázata között meglévő fontosabb eltéréseket megismerjük. A vizuális összevetésen túl a különböző vizsgált jellemzők térbeli mintázatának a heterogenitását a variációs koefficiens értékekkel $(\mathrm{CV} \%)$ is jellemeztük. Az értékelés során a 81 db mérési ponton mért LAI adatokat (6 év középértéke) és a pontsürüségi térképek alapján az ugyanezekre a helyekre számolt $\mathrm{N}_{1}$ és $\mathrm{G}_{1}$ értékeket használtuk fel. Az 1 ha-os területen a LAI variációs koefficiense volt a legalacsonyabb $(\mathrm{CV}=5,56 \%)$, a lokális törzsdenzitásé pedig a legmagasabb (13,71\%). A lokális körlapösszeg variációs koefficiense $11,53 \%$ volt. A három fó állományalkotó faj mintázatát külön-külön vizsgálva jelentősen magasabb variációs koefficienseket kaptunk. Az $\mathrm{N}_{1}$ térbeli heterogenitása a következő sorrendben csökken: $Q$. cerris $(94,08 \%)>A$. campestre $(55,72 \%)>Q$. petraea $(37,43 \%) . \mathrm{A} \mathrm{G}_{1}$ esetében a fajok sorrendje ugyanaz, de míg a $Q$. cerris esetében némileg egyenletesebb volt az eloszlás $(\mathrm{CV}=85,9 \%)$, addig az $A$. campestre $(66,18 \%)$ és a $Q$. petraea $(42,19 \%)$ esetében nagyobb heterogenitást tapasztaltunk. 


\section{Értékelés}

A faállomány struktúrája az erdei biodiverzitás legfontosabb befolyásoló tényezője, változása valamennyi élőlénycsoportra kihat (Tinya \& Ódor 2016). A faállományt leggyakrabban a hektáronkénti törzsdenzitással $\left(\mathrm{N}\right.$, egyed ha $\left.{ }^{-1}\right)$ és a hektáronkénti körlapösszeggel jellemzik $\left(\mathrm{G}, \mathrm{m}^{2} \mathrm{ha}^{-1}\right)$, amelyek megfelelő alapul szolgálnak a különböző erdőtípusok összehasonlító vizsgálatához és az erdőket ért zavarások hatásainak a felméréséhez. A zavarást követően lezajló erdődinamikai folyamatok során változások következnek be a faállomány struktúrájának a térbeli mintázatában, amelyek feltárásában egyre nagyobb szerepet kapnak a különböző térinformatikai eljárások.

A síkfőkúti LTER kutatóterület cseres-tölgyes állományában az 1970-es évek végétől kezdődő időszakban a domináns fák jelentős része elpusztult, drasztikusan átalakítva az állomány szerkezetét, és a korábban záródott lombkorona ritkulását, lékesedését idézve elő (Kotroczó et al. 2007). A tölgypusztulási hullám lecsengését követően megindult lombkorona-záródás során a tölgyfajok nem voltak képesek felújulni, a nyiladékokat a cserjeszintet domináló fajok kolonizálták (Misik et al. 2013, Misik et al. 2014). Eredményeink alapján az állomány funkcionális regenerációja a tölgypusztulást követően ennek ellenére sikeresnek tekinthető. Bár az állomány eredetileg kizárólag tölgyeket magába foglaló 816 egyed ha ${ }^{-1}$ törzsszáma (Jakucs et al. 1986) 2012-re a mezei juharral együtt is 464 egyed ha ${ }^{-1}$-ra csökkent, az élö fák 2012-ben mért $27.5 \mathrm{~m}^{2}$ ha $^{-1}$ körlapösszege csak kismértékben marad el az 1973-as $28.8 \mathrm{~m}^{2}$ ha $^{-1}$ adathoz (Jakucs 1986) viszonyítva. A variációs koefficiensek alapján a LAI általunk mért térbeli heterogenitása a lokálisan számolt törzsszámhoz és körlapösszeghez viszonyítva is alacsonynak bizonyult; az egyes pontokra számolt hatéves átlagok 3,63, illetve $4,88 \mathrm{~m}^{2} \mathrm{~m}^{-2}$ között szóródtak, mely tartomány összhangban van a szakirodalomban fellelhetö, elegyes tölgyállományokra közölt adatokkal (Bequet et al. 2011, Eriksson et al. 2005).

A lombkorona nyiladékok kolonizálásában a legsikeresebbnek a mezei juhar bizonyult, melynek sok egyede a lékekben felnőve fatermetűvé vált, második lombkoronaszintet alakítva ki napjainkra az állományban (Kotroczó et al. 2007). A felső lombkoronaszintet uraló tölgyek - elsősorban a kocsánytalan tölgy - mortalitási rátája napjainkra lecsökkent, a természetes mortalitás, illetve egyes kocsánytalan tölgy egyedek csúcsszáradással járó lombkorona-vesztesége azonban jelenleg is alakítja az állomány szerkezetét. A LAI és az egyes fajok, illetve a különböző egészségi állapotú kocsánytalan tölgyek térbeli mintázatának össze- 
hasonlítása alapján napjainkban azokat az állományrészeket jellemzi alacsonyabb levélfelület index, ahol:

- a kocsánytalan tölgy pusztulása ellenére viszonylag alacsony a mezei juhar egyedsürüsége $\left(\mathrm{N}_{1}<200 \mathrm{db} \mathrm{ha}^{-1}\right)$;

- $\quad$ a csertölgynek alacsony a lokális törzsszáma $\left(\mathrm{N}_{1}<150 \mathrm{db} \mathrm{ha}^{-1}\right)$; illetve

- a közelmúltban történt vagy jelenleg is zajlik fapusztulás (magas a holt és csúcsszáraz kocsánytalan tölgyek sürüsége).

Az eredményeink azt jelzik, hogy a LAI értéke magasabb az állományban ott, ahol:

- a kocsánytalan tölgy kisebb mértékben pusztult és/vagy magas a csertölgy törzsszáma; illetve

- ahol a viszonylag magas kocsánytalan tölgy törzsszám mellett megerösödött a mezei juhar is.

A legmagasabb LAI értékek a mintaterület azon részein voltak mérhetőek, ahol a mezei juhar a fapusztulást követően a tölgyek mellé gyorsan és sikeresen nőtt fel a lombkoronaszintbe. A mezei juharnak a mért LAI-ra gyakorolt erősen pozitív hatása annak köszönhető, hogy a faj viszonylag alacsony termetü egyedei nagyobb specifikus levélfelületü (,,árnyék”-jellegü) levelekkel (Eriksson et al. 2005), illetve sürübb lombkoronával (magasabb egyed-szintü LAI-val) jellemezhetök (Bréda 2003).

Az eredményeink alapján az alkalmazott térinformatikai eljárások lehetőséget adnak az állománystruktúra és az azt kialakító/módosító tényezők közötti kapcsolatok vizsgálatára. A módszerek korlátai miatt azonban ezen a téren jelenleg az elegyes erdóállományokra vonatkozóan sokkal kevesebb információ áll rendelkezésre, mint az elegyetlen erdőállományok esetében. Ezért a jövőbeni erdőökológiai kutatásokban fontos szerepet kap a különböző strukturális sajátosságok együttes térbeli elemzésére alkalmas új módszerek fejlesztése.

Az állománysürüséget jellemző mutatók $(\mathrm{N}, \mathrm{G})$ térbeli interpolációja során alapvetö jelentősége van az egyes pontok hatótávolságát kifejező keresési sugár optimalizálásának: a túl nagy sugár eltünteti a területi különbségeket, a túl kicsi sugár pedig izolált pontokat eredményez (Yang et al. 2006). A jelen tanulmányban vizsgált terület esetében 20 m-es sugár bizonyult optimálisnak, ennek az értéknek a megválasztása előzetes vizsgálatokat igényel és állományonként, vizsgálati objektumok szerint jelentősen különbözhet.

Elegyes erdóállományokban a kizárólag LAI-ra fókuszáló, és annak mérésére csupán indirekt módszert alkalmazó vizsgálatok során a fajok hatásának számszerủsítése nem egyszerủ feladat. Az egymással átfedő koronájú, különböző fajhoz tartozó fák hatása a LAI-ban együtt jelentkezik. Ráadásul a mérőmüszer érzékelési tartománya miatt az egymáshoz közeli pontokon végzett mérések is részben átfednek egymással, így a kapott térbeli mintázat kevésbé lesz tagolt. A mérési 
pontok sürüségét ezért a keresési sugár megválasztásához hasonlóan nagy körültekintéssel kell kijelölni (Nackaerts et al. 2000). Kellően sủrü és egyenletes eloszlású mérési ponthálózat esetén, mint a vizsgálatainkban alkalmazott módszernél, térinformatikai eljárással részletes LAI felület interpolálható, ami ismételt mérésekkel összetettebb tér- és időbeli vizsgálatokra is lehetőséget nyújthat (Wirth et al. 2001).

A síkfökúti kutatási területen végzett vizsgálataink megerösítik a korábban publikált eredményeket, miszerint a tölgypusztulás hatásai az erdő faállományában hosszú távon is megfigyelhetőek.

Köszönetnyilvánítás: Ezúton köszönjük az MTA ÖK Ökológiai és Botanikai Intézetének, hogy a vizsgálatokhoz rendelkezésünkre bocsátották a LAI-2000 mérőmüszert. Hálásan köszönjük a kézirat előző verzióját véleményező Bírálóknak a javaslataikat. A kutatásokat a LIFE08 ENV/IT/000399, az NKFIH K101552 és az NKFIH SNN_125652 projektek támogatták.

\section{Irodalomjegyzék}

Alessa, L., Kliskey, A. \& Brown, G. (2008): Social-ecological hotspots mapping: A spatial approach for identifying coupled social-ecological space. - Landsc. Urban. Plan. 85: 27-39. doi: https:// doi.org/10.1016/j.landurbplan.2007.09.007

Berki, I. \& Rasztovits, E. (2004): Zonális fafajaink, különösen a kocsánytalan tölgy szárazságtolerancia határérték sávjának kutatása: Módszer, előzetes eredmények. - In: Mátyás, Cs. \& Víg, P. (szerk.): IV. Erdö és klíma. pp. 209-219.

Bequet, R., Campioli, M., Kint, V., Vansteenkiste, D., Muys, B. \& Ceulemans, R. (2011): Leaf area index development in temperate oak and beech forests is driven by stand characteristics and weather conditions. - Trees 25: 935-946. doi: https://doi.org/10.1007/s00468-011-0568-4

Bréda, N. J. J. (2003): Ground-based measurements of leaf area index: a review of methods, instruments and current controversies. - J. Exp. Bot., 54: 2403-2417. doi: https://doi.org/10.1093/jxb/ $\underline{\operatorname{erg} 263}$

Cutini, A., Matteucci, G. \& Mugnozza, S. M. (1998): Estimation of leaf area index with the Li-Cor LAI 2000 in deciduous forests. - For. Ecol. Manage. 105: 55-65. doi: https://doi.org/10.1016/ S0378-1127(97)00269-7

Eriksson, H., Eklundh, L., Hall, K. \& Lindroth, A. (2005): Estimating LAI in deciduous forest stands. - Agr. For. Met. 129: 27-37. doi: https://doi.org/10.1016/j.agrformet.2004.12.003

Führer, E. (1998): Oak decline in central Europe: a synopsis of hypotheses. - In: McManus, M. L., Liebhold, A. M. (szerk..): Population Dynamics, Impacts, an Integrated Management of Forest Defoliating Insects. U.S. Department of Agriculture, Forest Service, Gen. Tech. Rep. NE-247, pp. 7-24.

Jakucs, P. (1985): Higher Plants. In: Jakucs, P. (szerk.): Ecology of an oak forest in Hungary - Results of "Síkfókút Project" 1. Akadémiai Kiadó, Budapest, Hungary, pp. 108-127.

Jakucs, P., Mészáros, I., Papp, B. L. \& Tóth, J. A. (1986): Acidification of soil and decay of sessile oak in the "Sikfökút Project" area (N-Hungary). - Acta Bot. Hung. 32: 303-322. 
Király, I. \& Ódor, P. (2010): The effect of stand structure and tree species composition on epiphytic bryophytes in mixed deciduous- coniferous forests of Western Hungary. - Biol. Conserv. 143: 2063-2069. doi: https://doi.org/10.1016/j.biocon.2010.05.014

Kotroczó, Zs., Krakomperger, Zs., Koncz, G., Papp, M., Bowden, R. D. \& Tóth, J. A. (2007): A síkfőkúti cseres-tölgyes fafaj-összetételének és struktúrájának hosszú távú változása. - Természetvédelmi Közlem. 13: 93-100.

Li, J. \& Heap, A. D. (2014): Spatial interpolation methods applied in the environmental sciences: A review. - Environ. Model. Softw. 53: 173-189. doi: https://doi.org/10.1016/j.envsoft.2013.12.008

Mátyás, Cs. \& Czimber, K. (2004): A zonális erdőhatár klímaérzékenysége Magyarországon előzetes eredmények. - In: Mátyás, Cs. \& Víg, P. (szerk.): IV. Erdő és klíma, pp. 35-44.

Mészáros, I., Veres, Sz., Kanalas, P., Oláh, V., Szöllősi, E., Sárvári, É., Lévai, L. \& Lakatos, Gy. (2007): Leaf growth and photosynthetic performance of two co-existing oak species in contrasting growing seasons. - Acta Silv. Lign. Hung. 3: 7-20.

Misik, T., Kárász, I. \& Tóthmérész, B. 2014. Understory development in an oak forest in NorthernHungary: the subcanopy layer. - Acta Silv. Lign. Hung. 10: 9-21. doi: https://doi.org/10.2478/ aslh-2014-0001

Misik, T., Varga, K., Veres, Zs., Kárász, I. \& Tóthmérész, B. 2013. Long-term response of understorey cover, basal area and diversity to stand density in a mixed oak forest on the Síkfõkút plot in Hungary. - J. For. Sci. 59: 319-327. doi: https://doi.org/10.17221/15/2013-jfs

Móricz, N., Rasztovits, E., Gálos, B., Berki, I., Eredics, A. \& Loibl, W. (2013): Modelling the Potential Distribution of Three Climate Zonal Tree Species for Present and Future Climate in Hungary. - Acta Silv. Lign. Hung. 9: 85-96. doi: https://doi.org/10.2478/aslh-2013-0007

Nackaerts, K., Coppin, P., Muys, B. \& Hermy, M. (2000): Sampling methodology for LAI measurements with LAI-2000 in small forest stands. - Agr. For. Met. 101: 247-250. doi: https://doi. org/10.1016/s0168-1923(00)00090-3

Tinya, F. \& Ódor, P. (2016): Congruence of the spatial pattern of light and understory vegetation in an old-growth, temperate mixed forest. - For. Ecol. Manage. 381: 84-92. doi: https://doi. org/10.1016/j.foreco.2016.09.027

Tóth, J. A. (2013): 40 éve az erdőökológiai kutatás szolgálatában: a Síkfökút Project. - Erdészettudományi Közlemények 3: 7-19.

Trumbore, S., Brando, P. \& Hartmann, H. (2015): Forest health and global change. - Science 349: 814-818. doi: https://doi.org/10.1126/science.aac6759

Wirth, R., Weber, B. \& Ryel, R. J. (2001): Spatial and temporal variability of canopy structure in a tropical moist forest. - Acta Oecologica 22: 235-244. doi: https://doi.org/10.1016/s1146609x(01)01123-7

Yang, D. H., Goerge, R. \& Mullner, R. (2006): Comparing GIS-Based Methods of Measuring Spatial Accessibility to Health Services. - J. Med. Sys. 30: 23-32. doi: https://doi.org/10.1007/ $\underline{\text { s10916-006-7400-5 }}$

http://pro.arcgis.com

http://www.icp-forests.org/Manual.htm 


\title{
Assessment of the small-scale spatial patterns in stand structure and leaf area index of the sessile oak-Turkey oak stand of Síkfókút LTER site
}

\author{
Balázs Adorján, Viktor Oláh, Péter Kanalas, Balázs Nyitrai \\ and Ilona Mészáros* \\ University of Debrecen Faculty of Science and Technology Department of Botany \\ H-4032 Debrecen, Egyetem tér 1, Hungary \\ e-mail*:immeszaros@unideb.hu
}

In the present work we investigated structural changes in the Turkey oak-sessile oak forest stand of Síkfökút LTER site (NE Hungary) which was previously affected by high tree mortality. From the 1970 'ies a significant proportion of the formerly dominating sessile oak (Quercus petraea) trees died leading to the emergence of previously suppressed species in the forming canopy gaps. The formed second canopy layer is primarily composed of field maple (Acer campestre) thus, besides the two oak species, we included this species to stand structure analyses. We assessed spatial patterns in tree density, basal area and leaf area index by means of geoinformatics. Comparing LAI and tree density maps of species we concluded that the field maple has positive effect on LAI while the presence of dying or dead oaks decreases its value. Our results also suggested that despite the large spatial heterogeneity in density and basal area of the tree layer and different species, the LAI showed small variations and more homogenous spatial pattern.

Keywords: LAI, climate change, forest change, field maple, sessile oak, Turkey oak 